Didych T. O. Monitoring the current state of law-formation in Ukraine: cognitive-legal aspects

The paper reveals the relevance of scientific knowledge of the current state of law-making in Ukraine. The cognitive role of monitoring as a means of cognitive activity is determined. The scientific basis of the research of the current state of law-formation in Ukraine is established. It is proved that an important element of scientific research is the cognitive aspects that characterize the investigated phenomenon or process as an element of reality, reflecting at the temporal level its current, actually existing at the time of knowledge, features. Their study enables to identify and generalize the current state of development of the investigated phenomenon or process, to carry out their critical analysis, to find out the existing disadvantages of functioning, to identify the prospects of development, formulate and substantiate the ways of their improvement. The indicated vector of scientific research is related to the establishment and synthesis of the features of the phenomenon under investigation or the process through the prism of their current state of development, which can be accomplished by conducting appropriate monitoring as a means of knowledge.

The author summarizes the scientific views of scientists concerning the understanding of the features of the current state of law-formation. It is concluded that in the modern legal science the problem studied is rather ambiguous, which is explained by the considerable discussion of the categorical understanding of the formation of law; significant activation of the formation of law, which takes place under the influence of the needs of the current state of social relations; the uncertainty of the prospect of the formation of law, due to the lack of a single doctrinal conceptual interpretation of the formation of law. The author summarizes the current state of development of law-making in Ukraine through the prism of cognitive possibilities of legal monitoring.

It is concluded that the development of the process of law-making is due not only to objective laws, but also to the subjective aspects associated with the influence on the process of formation of the right of the subjects of lawformation. One can conclude that the "state of development" in relation to the phenomenon of law-formation characterizes the formation of law as a real phenomenon, which, under the influence of objective and subjective factors, acquires, changes or deprives qualitative features, thereby affecting the qualitative features of the whole system of phenomena of legal reality. From the point of view of the methodology of scientific knowledge of the formation of law, its ability to develop determines the availability of appropriate developmental states at a specific time, and these states can be established and characterized by means of legal monitoring.

Key words: law-formation, law-making, legal formalization, legal monitoring, current state of law-making.

DOI: 10.33.66.3/2524-017X-2019-10-45-50

УДК 349.41

Павло Федотович Кулинич, доктор юридичних наук, професор, член-кореспондент НАПрН України, завідувач сектору проблем аграрного і земельного права Інституту держави і права ім. В. М. Корецького НАН України

\title{
МОНІТОРИНГ ЗЕМЕЛЬНИХ ВІДНОСИН В СИСТЕМІ ПРАВОВОГО МОНТТОРИНГУ: ПОНЯТТЯ, СТАНОВЛЕННЯ, ПЕРСПЕКТИВИ
}

Постановка проблеми. Здійснюваний в Україні правовий моніторинг являє собою діяльність органів державної влади, фахівців у галузі права, громадських організацій юридичного спрямування зі спостереження, оцінки та вдосконалення нормативної правової інформації та практики iii реалізації з метою підвищення ефективності правової системи. Відповідно у сучасній правовій доктрині України загальним об’єктом правового моніторингу на національному рівні визнається «...вся правова система, усі правові явища у межах кордонів держави, усі елементи механізму правового регулювання» [1, с. 92].

Аналіз останніх публікацій. Водночас правова система та механізм правового регулювання суспільних відносин мають досить складну структуру, що включає велику кількість відносно самостійних правових елементів, які також $є$ предметом правового моніторингу. Тому в літературі розглядаються різні аспекти та види правового моніторингу, зокрема, правовий моніторинг як засіб вдосконалення нормативно-правових актів [2 ], як адміністративно-правовий засіб забезпечення 
законності у правотворчій діяльності органів виконавчої влади [3 ], як засіб відомчої нормотворчості [4], як складова законотворчого процесу [5], як інструмент забезпечення ефективного функціонування правової системи [6]. Безперечно, основною метою здійснення правового моніторингу правозастосування $\epsilon$ вдосконалення правової системи, зокрема, двох ключових напрямів ііі функціонування - правотворчості та правореалізації. Водночас правовий моніторинг може бути не тільки універсальним засобом вдосконалення правової системи, а й ефективним засобом забезпечення належного розвитку ії складових елементів. Причому вибір таких складових для проведення правового моніторингу залежить від завдань, які ставить перед собою суб'єкт відповідної моніторингової діяльності.

Мета статті - провести доктринальний правовий аналіз моніторингу земельних відносин як особливого виду правового моніторингу, визначити його юридичну природу та сформулювати шляхи вдосконалення. За характером поставлених завдань розрізняють види правового моніторингу.

Основні результати дослідження. У літературі запропонований науковий підхід, згідно з яким у сфері правового регулювання суспільних відносин може здійснюватися моніторинг: суспільних відносин; правового поля; правового простору; правозастосовної практики; формалізованої правотворчості; муніципальної правотворчості; корпоративний моніторинг тощо. За такого підходу моніторинг суспільних відносин виділений в окремий вид і позначений першим у зазначеному переліку [1, с. 114]. Очевидно, автор такої класифікації видів правового моніторингу I. І. Онищук вважає, що моніторинг суспільних відносин може бути висхідною ланкою у формуванні системного правового моніторингу, який охоплює як правотворчість, так і правореалізацію. Адже він розглядає моніторинг суспільних відносин як систему «...теоретичних і емпіричних методів, за допомогою яких досліджуються суспільні відносини, що потребують правового регулювання, зміни чи скасування правового регулювання» [1, с. 114].

Не заперечуючи проти такого визначення статусу правового моніторингу суспільних відносин, що виникають у певних сферах суспільного життя, маємо зазначити, що у земельній сфері України практично відсутні земельні відносини, які б не були предметом правового регулювання. Саме тому, на наш погляд, вся земельна сфера $є$ правовою сферою. Це означає, що всі земельні відносини, що виникають у нашій країні, формуються під впливом правового регулювання і мають характер земельних правовідносин. Тому поява нових видів земельних відносин, наприклад, відносин щодо консолідації земельних ділянок тощо, може статися саме завдяки появі у земельному законодавстві нових правових норм. Отже, вищевикладене дає підстави для висновку про те, що оскільки всі земельні відносини мають форму правових відносин, то правовий моніторинг земельних відносин слід розглядати як різновид моніторингу правозастосовної практики.

Саме як моніторинг практики застосування норм земельного законодавства в нашій країні відбувається формування правового моніторингу земельних відносин. Причини його започаткування обумовлені тим, що земельні відносини в Україні $є$ найбільш «насиченою» корупцією сферою суспільного життя. Земля найчастіше стає об'єктом корупційних зловживань 3 боку посадових осіб органів влади, наділених певними земельними повноваженнями. Попри всі заходи боротьби з нею, земельна корупція в нашій державі не тільки не зникає, а й «захоплює» все нові території.

На наш погляд, розвиток корупції у земельних відносинах обумовлений трьома основними причинами. По-перше, в силу тривалого земельного мораторію сільськогосподарські землі в Україні це один з найцінніших та водночас дуже недооцінений ресурс, який притягує увагу як справжніх, так і псевдоінвесторів з метою отримання швидкого доходу. По-друге, в системі земельних відносин в Україні дуже велику питому частку займають ті з них, що виникають за участю посадових осіб органів влади. Посадові особи таких органів влади приймають рішення, надають дозволи та погодження, які мають характер юридичних фактів, на підставі яких формуються земельні правовідносини. По-третє, саме у сфері правового регулювання земельних відносин $є$ дуже багато темних, невидимих для широкого загалу «місць», які й використовують земельні корупціонери для вчинення протизаконних корисливих діянь. Такі місця криються не тільки у непрозорих, суперечливих та незрозумілих правових механізмах розподілу земель і вчинення земельних правочинів, а й, що дуже важливо - обумовлюються відсутністю або ж недоступністю інформації про рух земель як на національному, так і на регіональному та місцевому рівнях. Інформація про те, хто, коли, скільки і за скільки придбав землю та як її використовує тощо, $є$ важкодоступною для громадськості. По суті, недоступність відомостей про землю як основне національне багатство Украї- 
нського народу для самого народу і $€$ ключовою передумовою для інтенсивного розвитку земельної корупції в Україні та вчинення інших земельних правопорушень.

На наш погляд, одним із важливих шляхів подолання земельної корупції в нашій державі полягає у наповненні інформаційного простору відомостями про земельні відносини до такої міри, коли вчинення протиправних корисливих дій щодо землі як посадовцями, так і іншими особами стане небезпечним не тільки для країни, а й для них самих. Саме такий підхід до боротьби з земельною корупцією в Україні вирішили у 2014 році реалізувати Світовий банк, Міністерство аграрної політики і продовольства України, Держгеокадастр спільно з деякими іншими центральними органами виконавчої влади України у рамках Проекту «Підтримка реформ у сільському господарстві та земельних відносинах в Україні», який здійснювала Київська школа економіки у 2014-2018рp. [7]. Тоді було вирішено спробувати застосувати новий, оригінальний підхід до подолання корупції моніторинг земельних відносин.

Земельні відносини являють собою урегульовані нормами права відносини між людьми з приводу управління, володіння, користування, розпорядження землею та ії охорони. Відповідно моніторинг земельних відносин - це система постійного спостереження за їх формуванням з метою виявлення тенденцій, основних напрямів розвитку земельних відносин на рівні міст, районів, областей та на рівні країни в цілому. Тому результати такого моніторингу можуть використовуватися як при аналізі та оцінці діяльності органів влади та їх посадових осіб з питань організації земельних відносин, так і при вжитті на цій основі заходів з усунення виявлених недоліків організації земельних відносин та їх подальшого поліпшення.

Необхідність запровадження в Україні моніторингу земельних відносин як постійно оновлюваної інформаційної системи продиктована тим, що в нашій країні вся інформація про земельні відносини є розпорошеною, оскільки збирається і утримується різними відомствами та місцевими органами влади як відомча інформація з обмеженим доступом з боку інших владних інституцій, громадських організацій та приватних осіб. Тому така інформація далеко не повною мірою використовувалася для вирішення важливих економічних і соціальних проблем. Так, Державна фіскальна служба України володіє відомостями про податкову «дохідність» земель, Державна судова адміністрація України збирає дані про кількість та види судових спорів з приводу землі, Державна служба лісового господарства України збирає відомості про площі заліснених і незаліснених земель лісового фонду, Держгеокадастр України відображає інформацію про кількість та якість (цільове призначення тощо) земельних ділянок, Державний реєстр речових прав на нерухоме майно оперує відомостями про кількість та характеристики транзакцій щодо земельних ділянок, тощо. Такі відомості самі по собі є дуже цінними для оцінки розвитку відповідних земельних відносин. Однак, їх суспільне значення стало б значно вагомішим, якби всі наявні відомості про земельні відносини були сконцентровані в одному органі влади, стали співставними та взаємодоповнюючими. Адже через розпорошеність вищезгаданої земельної інформації центральні органи влади далеко не завжди мають змогу побачити «цілісну картину» розвитку земельних відносин як на рівні районів та областей, так і на національному рівні. Крім того, навіть наявна інформація про земельні відносини відсутня у відкритому доступі і тому не використовується для вирішення важливих проблем розвитку країни. Натомість брак відомостей про земельні відносини якраз і сприяє виникненню «темних інформаційних зон», завдяки яким посадовці та пов'язані з ними спільними корисливими намірами особи використовують землю у своїх інтересах всупереч національним та місцевим публічним інтересам.

Об'єднання в одній системі всього спектра даних про земельні відносини, які надходять до різних відомств, сприяє закриттю таких інформаційних зон, оскільки дає фактологічну основу для аналізу ситуації, виявлення тенденцій, проблемних позицій, прогнозування та моделювання розвитку ситуації у земельній сфері та земельного законодавства як правової бази формування земельних відносин. Тому така система відомостей $є$ необхідним фундаментом для розробки обгрунтованої державної політики у сфері розвитку земельних відносин, а також для виявлення позитивних і негативних тенденцій у їх розвитку на рівні областей, районів і міст. Як свідчить вітчизняна практика, саме відсутність таких узагальнених даних у відкритому доступі є однією з причин неспроможності української економіки використовувати потенціал земельних ресурсів повною мірою, породжує політичні спекуляції щодо необхідності, стану та напрямків земельного реформування, а також сприяє приховуванню помилок і корупційних діянь у діяльності органів влади, наділених земель- 
ною компетенцією. Відтак доступність таких даних для широкого загалу є основою для підвищення рівня прозорості земельної сфери та подолання земельної корупції.

Таким чином, моніторинг земельних відносин передбачає узгоджену діяльність низки органів державної влади зі збору, систематизації, збереження та оприлюднення набору даних та показників, які характеризують стан земельних відносин в Україні.

При запровадженні у 2014 році за участі Світового банку пілотного проекту одним із його завдань було 3'ясування можливості створення в Україні автоматизованої інформаційної системи моніторингу земельних відносин, яка б акумулювала актуальні достовірні дані про фактичний стан земельних відносин в Україні, що надходять від місцевих органів влади до різних відомств. Для цього був проведений свого роду аудит наявних джерел інформації про землю, ступеню iii уніфікованості, повноти та регулярності надходження (оновлення), а також розроблення методології та проведення тестування спроможності відповідних органів влади взаємодіяти у проведенні моніторингу земельних відносин. В результаті виконання вищезазначеного пілотного проекту була створена пробна інформаційна система, яка дозволяла аналізувати поточний стан земельних відносин за кожним із понад 140 їх показників.

Для проведення пілотного моніторингу земельних відносин були об'єднані зусилля шести відомств: Державної служби статистики України; Державної служби України з питань геодезії, картографії та кадастру, Державної судової адміністрації України, Державної фіскальної служби України, Державного агентства водних ресурсів України та Міністерства юстиції України (ДП «Національні інформаційні системи»). 3 числа їх представників цих була створена Міжвідомча робоча група з моніторингу земельних відносин, яка й забезпечила розробку показників земельних відносин для потреб їх моніторингу, порядку отримання від органів влади відповідних даних під час здійснення пілотного проекту, а також надавала пояснення щодо отриманих результатів моніторингу. В результаті був підготовлений перший в Україні доступний для всіх бажаючих довідник, який містить інформацію про стан земельних відносин на підставі тих відомостей, що акумулюються у Держгеокадастрі України та в інших центральних органах влади у процесі їх діяльності. Отже, пілотний проект з проведення моніторингу земельних відносин в нашій країні виявився успішним.

Однак, у процесі здійснення цього пілотного проекту були виявлені і певні складнощі. Адже даний пілотний проект здійснювався неофіційно. Так, міністерства і відомства, чиї представники увійшли до складу зазначеної Міжвідомчої робочої групи з проведення пілотного проекту, та й сама робоча діяли неофіційно, оскільки в Україні відсутня повноцінна правова база для здійснення моніторингу земельних відносин: проведення такого моніторингу не передбачене ні Земельним кодексом України, ні іншими законодавчими актами. Саме через законодавчу неврегульованість моніторингу земельних відносин здійснення пілотного проекту було ускладненим. Зокрема, мало місце невчасне надання деякими міністерствами і відомствами інформації про стан земельних відносин або ж вона надавалася в неуніфікованій формі тощо.

В зв'язку з цим Кабінет Міністрів України вирішив запровадити постійний моніторинг земельних відносин своєю постановою. Однак, відповідно до ст. 49 Закону України «Про Кабінет Міністрів України» [8] Уряд має право видавати обов'язкові для виконання акти - постанови i розпорядження - лише на основі та на виконання Конституції і законів України, актів Президента України, постанов Верховної Ради України, прийнятих відповідно до Конституції та законів України. Однак, в жодному з чинних законів, постанов Парламенту чи указів Президента не передбачено ведення моніторингу земельних відносин. В цій правовій ситуації Міністерство аграрної політики та продовольства та Державна служба з питань геодезії, картографії та кадастру запропонували Кабінету Міністрів України продовжити ведення такого моніторингу у пілотному режимі на основі підзаконного правового акта. Для цього 23 серпня 2017 р. Кабінет Міністрів України прийняв постанову № 639 «Про реалізацію пілотного проекту щодо проведення моніторингу земельних відносин та внесення змін до деяких постанов Кабінету Міністрів України» [9 ], згідно з якою 1 вересня 2017 р. по 1 березня 2019 пілотний проект щодо проведення моніторингу земельних відносин мав здійснюватися на основі цього правового акта.

На виконання зазначеної постанови Міністерство аграрної політики та продовольства України надіслало на офіційну пошту Держводагентства, Держстату, Мін'юсту, Держгеокадастру, Державної фіскальної служби і Державної судової адміністрації форму-анкету, в якій об'єднані ключові показники, що характеризують земельні відносини в Україні: кількість ділянок, їх межі, повнота 
даних у реєстрах, кількість транзакцій, надходження від земельного податку, приватизація і судові тяжби за землю - загалом понад 140 параметрів - все, 3 чим кожен день стикаються громадяни та органи місцевого самоврядування, але що досі не можна було ні оцінити, ні об'єднати на національному рівні.

Тепер шість зазначених вище відомств стали регулярно обмінюватися даними, виконуючи постанову Уряду. Спочатку, у напівручному режимі, зусиллями Держгеокадастру, який $є$ виконавцем пілотного проекту, а після створення спеціального програмного забезпечення - автоматично. Результатом має стати створення єдиного електронного відкритого для зовнішнього контролю масиву даних, який дозволяє відстежувати динаміку земельних відносин. На нашу думку, саме завдяки такій відкритій і доступній для всіх базі відомостей про землю суспільство може завдати нищівного удару по земельній корупції.

На наш погляд, здійснюваний на підставі урядової постанови моніторинг земельних відносин доцільно зробити постійним, зміцнивши правові основи його проведення шляхом прийняття відповідного закону. По-перше, необхідність прийняття такого закону випливає з Конституції України, стаття 19 якої проголошує, що органи державної влади, органи місцевого самоврядування та їх посадові особи зобов'язані діяти лише на підставі, в межах повноважень та у спосіб, що передбачені Конституцією та законами України. Отже, саме законом можна сформувати правові підвалини для правомірної роботи органів влади та їх посадових осіб щодо ведення моніторингу земельних відносин. По-друге, моніторинг земельних відносин дозволяє не тільки сприяти подоланню земельної корупції. Зібрані в результаті його проведення відомості дають також можливість формувати і проводити обгрунтовану, ефективну і цілеспрямовану земельну політику на національному рівні, планувати вжиття заходів щодо раціонального використання та охорони земель на регіональному та місцевому рівнях, а також здійснювати як державний, так і громадський контроль за їх реалізацією. Адже не секрет, що переважна більшість наших державних і місцевих програм складаються без повного володіння інформацією про стан земельних відносин. Відповідно такі програми дуже часто не виконуються. Тому моніторинг земельних відносин дозволить усунути цей недолік.

В зв'язку з цим автором цієї статті був підготовлений проект Закону України «Про внесення змін і доповнень до деяких законодавчих актів щодо моніторингу земельних відносин», який 18 січня 2018 р. був внесений у Верховну Раду України (№7502) народними депутатами України. Перш за все, даним законопроектом передбачається внести до Земельного кодексу України доповнення, спрямовані на надання моніторингу земельних відносин статусу постійної функції органів державного управління у сфері використання та охорони земель. 3 цією метою Кодекс пропонується доповнити новим розділом VII-1 «Моніторинг земельних відносин» у складі трьох статей, які визначають принципові положення такого моніторингу: поняття, зміст, принципи ведення та порядок організації. Крім того, законопроектом передбачається уточнити визначення земельних відносин, яке закріплене у ст. 2 Земельного кодексу України. У цій статті зазначено, що земельні відносини - це суспільні відносини щодо володіння, користування і розпорядження землею. Проте дане визначення фактично зводить зміст земельних відносин до одного з їх різновиду - відносин власності на землю. Натомість на практиці виникають й інші види земельних відносин, які регулюються чинним земельним законодавством, зокрема, відносини щодо управління земельними ресурсами та відносини з охорони земель. Саме ці види земельних відносин доцільно піддавати прискіпливому моніторингу. Тому ми пропонуємо викласти статтю 2 Земельного кодексу України у редакції, яка б визначала, що земельні відносини являють собою суспільні відносини щодо управління володіння, користування і розпорядження землею та іiі охорони. Нарешті зареєстрованим нами законопроектом пропонується визначити органи влади, які зобов'язані брати участь у проведенні моніторингу земельних відносин у межах їх повноважень, надаючи наявну в них земельну інформацію в загальний банк відомостей, які формуються в результаті проведення моніторингу земельних відносин.

Висновки. Правовий моніторинг може бути не тільки універсальним засобом вдосконалення правової системи, а й ефективним засобом забезпечення належного розвитку ії складових елементів. Вибір таких складових для проведення правового моніторингу залежить від завдань, які ставить перед собою суб'єкт відповідної моніторингової діяльності. Моніторинг земельних відносин являє собою узгоджену діяльність низки органів державної влади зі збору, систематизації, збереження та оприлюднення набору даних, які характеризують стан земельних відносин в Україні за обраною 
системою показників. Основною причиною запровадження в Україні земельного моніторингу є розвиток земельною корупції, якій сприяють три фактори: 1) недооціненість сільськогосподарських земель, яка притягує як справжніх, так і псевдоінвесторів 3 метою отримання швидкого доходу; 2) наявність в системі земельних відносин в Україні дуже великої питомої частки таких 3 них, що виникають за участю посадових осіб органів влади; 3) наявність у сфері правового регулювання земельних відносин прогалин, неточностей та суперечностей, які й використовують земельні корупціонери для вчинення протизаконних корисливих діянь. Оскільки земельні відносини мають характер земельних правовідносин, моніторинг земельних відносин $є$ різновидом моніторингу правозастосовної практики у земельній сфері. У становленні моніторингу земельних відносин в Україні можна виділити такі етапи: 1) неофіційний пілотний етап (1916-1917рр.), який здійснювався відповідними органами влади з ініціативи і за підтримки Світового банку; 2) офіційний пілотний етап (1917-1919рр.), який здійснюється на основі підзаконного правового акта - постанови Кабінет Міністрів України від 23 серпня 2017 р. № 639 «Про реалізацію пілотного проекту щодо проведення моніторингу земельних відносин та внесення змін до деяких постанов Кабінету Міністрів України». Моніторинг земельних відносин має бути постійним; йому має бути наданий статус окремої функції органів влади щодо управління земельними ресурсами. Для забезпечення правового статусу моніторингу земельних відносин як постійної функції органів влади у сфері управління земельними ресурсами доцільно прийняти спеціальний закон.

\section{Список використаних джерел}

1. Онищук I. I. Правовий моніторинг: проблеми методології, теорії та практики : моногр. / I. І.Онищук. - ІваноФранківськ - Дрогобич : Коло, 2017. - 512 с.

2. Косович В. М. Правовий моніторинг як засіб вдосконалення нормативно-правових актів України//Науковий вісник Львівського державного університету внутрішніх справ. - 2012. - № 3. - С. 31-44.

3. Лисенко M. О. Правовий моніторинг як адміністративно-правовий засіб забезпечення законності у правотворчій діяльності органів виконавчої влади // Часопис Київського університету права. - 2014. - № 3. - С. 101-105.

4. Градова Ю. В. Правовий моніторинг відомчої правотворчості // Науковий вісник Ужгородського національного університету. - 2013. - Серія Право. Випуск 22. Частина I. Том 1. - С. 90-94.

5. Нижник Н. Р. Правовий моніторинг як необхідна складова законотворчого процесу // Вісник Центральної виборчої комісії. - 2014. - № 2 (29). - С. 51-54.

6. Онищук I. I. Правовий моніторинг - інструмент забезпечення ефективного функціонування правової системи // Науково-інформаційний вісник. - 2013. - № 8. - Право. - С. 72-80.

7. Проекm «Підтримка реформ у сільському господарстві та земельних відносинах в Україні»// http://www.kse. org.ua/uk/research-policy/land/about/

8. Відомості Верховної Ради України. - 2014. - № 13. - Ст. 222.

9. Офіційний вісник України. - 2017. - № 70. - Ст. 2123.

\section{Reference}

1. Onyshchuk I. I. Pravovyi monitorynh: problemy metodolohii, teorii ta praktyky: monohrafiia / I.I.Onyshchuk. Ivano-Frankivsk - Drohobych : Kolo, 2017. - $512 \mathrm{~s}$.

2. Kosovych V. M. Pravovyi monitorynh yak zasib vdoskonalennia normatyvno-pravovykh aktiv Ukrainy // Naukovyi visnyk Lvivskoho derzhavnoho universytetu vnutrishnikh sprav. - 2012. - № 3.- S. 31-44.

3. Lysenko M. O. Pravovyi monitorynh yak administratyvno-pravovyi zasib zabezpechennia zakonnosti u pravotvorchii diialnosti orhaniv vykonavchoi vlady//Chasopys Kyivskoho universytetu prava. - 2014. - № 3. - S. 101-105.

4. Hradova Yu.V. Pravovyi monitorynh vidomchoi pravotvorchosti//Naukovyi visnyk Uzhhorodskoho natsionalnoho universytetu. - 2013. - Seriia Pravo. Vypusk 22. Chastyna I. Tom 1. - S. 90-94.

5. Nyzhnyk N. R. Pravovyi monitorynh yak neobkhidna skladova zakonotvorchoho protsesu//Visnyk Tsentralnoi vyborchoi komisii. - 2014. - № 2 (29). - S. 51-54.

6. Onyshchuk I. I. Pravovyi monitorynh - instrument zabezpechennia efektyvnoho funktsionuvannia pravovoi systemy // Naukovo-informatsiinyi visnyk. - 2013. - № 8. - Pravo. - S. 72-80.

7. Proekt «Pidtrymka reform u silskomu hospodarstvi ta zemelnykh vidnosynakh v Ukraini»// http://www.kse.org.ua/ uk/research-policy/land/about/

8. Vidomosti Verkhovnoi Rady. 2014. - № 13. - St. 222.

9. Ofitsiinyi visnyk Ukrainy. - 2017. - № 70. - St. 2123. 
Кулинич П. Ф. Моніторинг земельних відносин в системі правового моніторингу: поняття, становлення, перспективи

У статті досліджуються поняття і становлення моніторингу земельних відносин як окремого виду правового моніторингу та перспективи його законодавчого забезпечення. Обгрунтовується висновок, що моніторинг земельних відносин являє собою узгоджену діяльність низки органів державної влади зі збору, систематизації, збереження та оприлюднення відомостей, які характеризують стан земельних відносин в Україні за обраною системою показників. Основною причиною запровадження в Україні земельного моніторингу є розвиток земельної корупції, якій сприяють три фактори: 1) недооціненість сільськогосподарських земель, яка притягує як справжніх, так і псевдоінвесторів 3 метою отримання швидкого доходу; 2) наявність в системі земельних відносин в Україні дуже великої питомої частки таких з них, що виникають за участю посадових осіб органів влади; 3) наявність у сфері правового регулювання земельних відносин прогалин, неточностей та суперечностей, які й використовують земельні корупціонери для вчинення протизаконних корисливих діянь. 3 метою надання моніторингу земельних відносин статусу функції органів управління земельними ресурсами пропонується прийняти відповідний закон.

Ключові слова: правовий моніторинг, земельна корупція, моніторинг земельних відносин.

Kulynych P. F. Monitoring of land relations in the system of legal monitoring: notion, development, prospective (abstract)

Notion of monitoring of land relations as well as pace of its development as a separate type of legal monitoring are researched. The author of the article proves that legal monitoring may serve not only as universal mean of improvement of legal system at all, but it can be used as effective mean for promotion of proper development of elements of the legal system. Selection of such elements for conducting of legal monitoring depends on the tasks the proper monitoring activity is aimed at solving of. So monitoring of land relations can be defined as agreed activity of a number of state power bodies regarding collection, systematization, preservation and promulgation of data, which characterizes status of land relations in Ukraine on selected system of indicators. Main reason for starting of monitoring of land relations in Ukraine consists in presents of land corruption which is promoted by three factors such as: 1) agricultural lands are underestimated, and underestimation of such lands attracts both real and pseudo-investors willing to receive quick income; 2) in the structure of land relations there are very high specific share of those ones which directly depends on will of state bodies" officials;3) presence in the sphere of legal regulation of land relations gaps, unclear provisions and contradictions which are used by land corruptors for illegal mercenary actions. Taking into account that land relations in Ukraine are legal relations (it means relations which are regulated by law), monitoring of land relations is a kind of monitoring of law implementing practice in land sphere. There are such stages which can be highlighted in incipience of land relations namely:1) unofficial pilot stage (1916-1917), which was being implemented by proper state bodies under initiative and with support of World Bank; 2) official pilot stage (1917-1919), which is being implemented on the basis the bylaw - resolution of Cabinet of Ministers of Ukraine of August 23, 2017, number 639 «On implementation of pilot project regarding conducting of monitoring of land relations and introduction of changes into some resolutions of Cabinet of Ministers of Ukraine». Also the author of the articles argues that monitoring of land relations has to be introduced as permanent state activity; so it has to be assigned a status of separate function of state bodies in the sphere of land management. The conclusion is formulated that the monitoring of land relations is agreed activity of group of state power"s bodies regarding collection, systematization, preservation and promulgation of data, which characterizes status of land relations in Ukraine on selected system of indicators. To provide the monitoring of land relations with status of state bodies" function of land management it is proposed to adopt proper law.

Key words: legal monitoring, land corruption, monitoring of land relations.

DOI: $10.33 .66 .3 / 2524-017 X-2019-10-50-56$ 